\title{
А.В. Стогова
}

\section{ЗАПАХ СЛОВ: ЧУВСТВИТЕАЬНОСТЬ К ЯЗЫКУ И СОЦИАЛЬНЫЕ ИЕРАРХИИ B РАБОТАХ ФРАНСУА АЕ КАМЬЕРА}

КМючевЫЕ словА: чувствительность, речь, бесеАа, социальная иерархия, страсть, разум, Франсуа де Кальер

Аннотация: в статье поднимается актуальная в современных гуманитарных исследованиях проблематика истории ощущений, рассматриваемая применительно к устной и письменной речи как чувственному и эмоциональному опыту. Основой Аля исследования стали работы о манере речи Франсуа де Кальера, изданные в конце XVII века. В статье прослеживается, с каких позиций Кальер анализирует речь своих современников, какими чувственными характеристиками он наделяет ее в текстах и как чувственная ипостась речи становится Аля него способом конструирования различных социальных иерархий и идеального образа человека.

Изучение чувств (как ощущений) в исторической перспективе при всем стремлении историков расширить поле исследований и сделать материальные и визуальные свидетельства эпохи не второстепенным, а ключевым источником информации, тем не менее, неизбежно обращаются к текстам в поисках сведений о том, какой чувственный опыт и каким образом находит свое выражение в речи. Однако и вопросы языка, ставшие уже традиционными в исторических исследованиях, этот подход позволяет изучить с новых позиций. В данной работе предлагается обратиться именно к этой проблематике. В центре внимание окажется вопрос о

Анна Вячеславовна Стогова, к.и.н, с.н.с. ОтАеления историко-теоретических исслеАований ИВИ РАН, Аоцент КафеАры истории и теории культуры Факультета культурологии РГГУ, anna100gova@yandex.ru 
том, в какой мере сама речь может восприниматься как источник позитивных или негативных чувственных ощущений, и каким образом этот чувственный опыт связан с вопросами социального порядка.

XVII век отмечен интересом к чувственному и эмоциональному опыту, который, как отмечают исследователи, был связан со множеством различных явлений. К ним можно отнести радикальные новшества в искусстве - от голландской живописи до итальянской оперы, новое знание и философия, формирование «модного» образа жизни социальной элиты, выражавшегося, помимо прочего, в изобилии чувственных удовольствий. При этом для конца XVII века какого-то очевидного различия эмоций и ощущений, полученных от органов чувств, еще не существовало. Эмоциональные переживания не отделялись от чувственного опыта, который эти эмоции порождал, а чувственный опыт нередко описывался как опыт эмоциональный. Идея чувственной насыщенности, отличавшая образ жизни при дворе, подразумевала ошеломление, удивление и восхищение, неразрывно связанные с блеском золота и зеркал, изысканными звуками музыки, запахами экзотических цветов и вкусами заморских напитков. Размах этой новой культуры приведет в XVIII веке к различным концепциям чувственной умеренности, необходимой для душевного здоровья. ${ }^{1}$ Слово эмоция еще не использовалось в современном значении ${ }^{2}$, при описании эмоционального, чувственного опыта речь шла о «страстях». И в изучении страстей, как

1 См. об этом: A Cultural History of the Senses. 2014: 1-20.

2 Сложность определений, с которыми приходится иметь дело заставляет их обращать пристальное внимание на те языковые категории, которыми эмоциональный и чувственный опыт описывался не только в прошлом, но и в настоящем. В частности на саму уместность термина "эмоции" в поАобных исследованиях. См., например: Reading Early Modern Passions. 2004: 1-20. 


\section{Стогова А.В. Запах слов}

с позиции науки, так и с точки зрения морали абсолютно превалировал интерес к различению страстей и разума и возможности установления контроля разума над страстями. ${ }^{3}$

Но многочисленные и разнообразные тексты о «страстях души» могут быть рассмотрены и с точки зрения поиска адекватного языка, которым можно описывать чувственно-эмоциональный опыт и при помощи которого его можно выражать. Помимо интереса к чувственной стороне жизни, XVII столетие, когда, по словам Мишеля Фуко, слова и вещи только начали обретать свои различия ${ }^{4}$, известно огромным интересом к языку и речи - строению, функциям, способности оказывать то или иное воздействие и формировать коммуникацию. Помимо появления словарей и грамматик национальных языков, которые впервые составляются и публикуются для широкой аудитории, а также всевозможных пособий по риторике, необходимо отметить все возрастающее внимание к манере речи.

Это внимание также отчасти обусловлено формированием феномена моды, включавшего не только наряды и предметы быта, но стиль жизни в целом, который в эпоху развития салонной культуры был неразрывно связан с культурой речи и разговора. Специфическая галантная форма выражения любовной привязанности, прециозная рафинированная и вычурная манера речи или «любезность» как основополагающая категория общения в равной мере служили маркером особого поведения, свойственного салонной и придворной культуре. Как отмечает Мириам Мэтр, изучение искусства беседы «предполагает, что следует принять во внимание все составляющие ситуации: вербальное и невербальное общение, ин-

4 Фуко. 1994: 79. 
тонацию, жестикуляцию, коды пространственного поведения, туалеты, пространство и его характеристики и т.п.»5. Учитывая то значение, которое чувственность играла в определении этого образа жизни, неудивительно, что манера речи в XVII веке также были неразрывно связаны с чувственным восприятием ${ }^{6}$.

Подавляющее большинство работ о речи были посвящены определению и обоснованию ее «правильной» и достойной манеры. На этом фоне выделяются сочинения Франсуа де Кальера, которые были изданы в 1690-е годы. Они интересны не только тем, что в них критикуются нередко «модные», но неправильные манеры поведения. Эти работы в полном согласии с идеями Норберта Элиаса, демонстрируют чувствительность к чужому поведению - в данном случае к речи. Не случайно Элиас для иллюстрации тезиса об изменении чувствительности и придворном моделировании речи ссылается именно на них. ${ }^{7}$ Объектом критики Кальера являются слова и выражения, которые вызывают отторжение и неприятие, так что в данном случае чувствительность к языку подразумевает и способность различать языковые тонкости и нюансы, и чувствительно реагировать на произносимые слова. Вербальное общение представлено как опыт телесного присутствия и телесной реакции, куда входят и эмоции, которые являются, согласно идеям того времени, реакцией организма на внешние раздражители, воздействующие на органы чувств. Это опыт в первую очередь аудиальный, тесно связанный со всем комплексом ощущений такого телесного присутствия, т.е. внешним видом собеседника, его манерами и запахами.

5 Maitre. 1999: 459.

6 Параммельно начинаются Аискуссии об искусстве оперы и о роли голоса и манеры исполнения в "возбуждении страстей». См. об этом: Nancy. 2012. О специфике восприятия женского голоса см. также: Стогова. 2017.

Эмиас. 2001: І. 161, 171, 177-182; II. 299. 
Для начала необходимо сказать несколько слов о самом Кальере, поскольку он известен в России только историкам дипломатии, а, между тем, его отношение и к языку, и к социальным иерархиям в значительной мере обусловлено собственным жизненным опытом. Франсуа де Кальер (16451717) был старшим из сыновей 8 Жака де Кальера (?-1662) — губернатора Шербура, известного не только как военный деятель, но и как литератор. Он был одним из основателей литературной академии в Кане, поддерживал близкие отношения с Жаном Шапленом ${ }^{9}$ и сам был автором нескольких работ, в числе которых «История герцога Жуайеза» и «История маршала Матиньона», а также пособие для желающих преуспеть при дворе «Фортуна людей благородного происхождения». Происхождение самого Жака де Кальера до сих пор остается загадкой. Долгое время считалось, что это боковая ветвь дворянского семейства Кальеров из Сантонжа, однако эта версия была подвергнута сомнению10. В то же время Жак де Кальер получил образование, приличествую-

8 Его млаАший брат ^уи-Эктор де Кальер (1648-1703) стал губернатором Новой Франции, т.е. Канады, обе сестры вышли замуж в Нормандии, но не смогли своим браком усилить положение семьи.

9 Жан Шаплен (1595-1674) - французский поэт и китературный критик, член Французской академии.

10 Жан-Клод Ваке подробно разбирает, в силу каких новых данных эта версия постепенно становилась все менее правдоподобной. Waquet. 2005: 39-40. Что касается происхождения этой версии, то можно предположить, то ее автором был именно Франсуа де Кальер, именно он изменил написание своей фамилии таким образом, чтобы оно совпадало с написанием фамилии своих "родственников" - de Callières. Его отец писал свою фамилию иначе - de Caillierès, Аа и первый митературный труА Франсуа Ka^ьера вышел поА тем же именем. Аюбопытно, что в конце XVIII столетия Кальеры из Сантонжа признали во Франсуа своего родственника. Waquet. 2005: 40. В то же время надо отметить, что ряА исследователей и сейчас продолжают придерживаться версии о Аворянском происхождении Кальера и его связях с сантонжским семейством. См., например: Shweizer. 1995: 2; Lempereur. 2002: 9. 
щее дворянину, но очень разностороннее для провинциального и небогатого семейства начала XVII века, женился на дочери обедневшего дворянина и вел явно дворянский образ жизни. Эти странности вкупе со свидетельствами об активном покровительстве Жаку де Кальеру со стороны знатного и влиятельного нормандского семейства Матиньонов ${ }^{11}$ и многими другими обстоятельствами позволили Лоуренсу Поупу предположить, что Жак де Кальер был внебрачным сыном представителя какого-то знатного рода - либо Матиньонов, либо их еще более влиятельных родственников де Лонгвилей ${ }^{12}$ - одного из самых знатных французских семейств ${ }^{13}$. Эта гипотеза очень многое объясняет и в отношении Франсуа де Кальера - как его судьбы и карьеры, так и взглядов в отношении аристократии, которые он высказывал в своих работах. Значительная доля критики у него направлена против спесивых аристократов, которые полагают, что они принадлежат к людям особой породы, хотя на самом деле, говорит Кальер, «даже не надо углубляться в историю до Адама», чтобы убедиться в том, что все в той или иной мере являются друг другу родственниками 14.

11 Матиньоны - знатный нормандский Аворянский род, владевший наслеАственной Аолжностью генерал-губернаторов Нормандии.

12 Род герцогов Ае Аонгвилей восходит к Жану Ае Аюнуа, побочному сыну герцога ^уи Орлеанского, который в свою очередь был млаАшим сыном короля Карла V и дедушкой короля Аюдовика XII. Шарль де Матиньон был женат на Элеоноре Орлеанской, Аочери герцога де Аонгвиля. Их сын Франсуа и стал покровителем Кальера.

13 Роре. 2010: 4-6. ОАним из непосредственных свидетельств в пользу этой версии является замечание Ж. -Э. Пиганьоля Ае ^а Форса в его "Описании Парижа, Марли, Сен-Клу, Фонтенбло и всех прочих прекрасных домов и замков в окрестностях Парижа" 1742 г. изАания: "Вероятно, о происхожАении Ж. Ае Кальера было бы больше известно, будь оно менее блестящим" Piganiol de La Force. 1742: 531.

14 Callières. 1693b: 50. 


\section{Стогова А.В. Запах слов}

Об образовании, которое получил Франсуа де Кальер, нет достоверных сведений. Можно предположить, что он обучался в коллеже д'Аркур, как и большинство детей нормандских дворян. Этот коллеж известен своими проянсенистскими взглядами, и следы влияния янсенизма исследователи находят в различных работах Кальера. В частности, его юношеский опус «Логика влюбленных, или Амур-логик» (1668) отсылает к знаменитой «Логике Пор-Рояля» Пьера Николя и Антуана Арно и на основе любовной тематики критикует схоластическую логику. Этот аспект для нас тоже немаловажен, поскольку все работы о языке у Кальера пронизаны идеями рационализма и рационального устройства языка и, по всей видимости, восходят к творениям янсенистов, во многом опиравшихся на метод Декарта и философию Паскаля: не только к «Логике», но и «Грамматике ПорРояля» Антуана Арно и Клода Лансло. Кальер не упоминает ни один из этих текстов, поскольку рассуждает о манере речи, а не языке самом по себе, но ссылается на Паскаля, другого известного янсениста. И все это заставляет предполагать, что, по всей видимости, с грамматикой он был знаком. Если он и не обучался в коллеже д’Аркур, то, по меньшей мере, на протяжении всей жизни находился под покровительством людей, очень близких к Пор-Роялю, начиная от герцогини де Лонгвиль ${ }^{15}$ и заканчивая герцогом де Шеврёзом ${ }^{16}$. Равным

15 Анна-Женевьева Ае Бурбон-Конде (1619-1679), супруга Анри II Орлеанского, герцога де Аонгвиль. В период опалы за активное участие во ФронАе становится ярой сторонницей янсенизма и покровительницей монастыря Пор-Рояль.

16 Шарль-Оноре А’Альбре, герцог Ае Шеврёз (1646-1712) - один из фаворитов и советников АюАовика XIV, внук герцогини де Шеврёз - еще оАной активной участницы Фронды, попавшей в последние гоАы жизни поА влияние янсенизма. Учителем герцога был Блез Паскаль, а Жан Расин, сам обучавшийся в Пор-Рояле, посвятил ему трагедию “Британник". 
образом Кальер интересовался и эмпиристической традицией, и известно, что в посмертной описи его имущества среди прочих книг было упомянуто первое французское издание «Опыта о человеческом разумении» Джона Локка 1700 года ${ }^{17}$.

Жак де Кальер умер, когда сыну еще не было и 20 лет, и Франсуа обращается за помощью к покровителям отца, в результате чего семейство Лонгвилей отправляет его в Польшу в качестве одного из членов тайной миссии, целью которой была попытка возвести на польский престол графа де Сен-Поль, будущего герцога де Лонгвиль ${ }^{18}$. Лишенный семейных связей и значительного капитала, Кальер выстраивает свою карьеру через влиятельных покровителей. Став профессиональным дипломатом, он долгое время находился на службе то одних, то других влиятельных лиц, постепенно обрастая необходимыми связями. Сначала это были де Лонгвили, затем семейство герцога Савойского ${ }^{19}$, люди из окружения Кольбера ${ }^{20}$, польский аристократ Мор-

17 Collection des documents. 1885: 136. K сожалению, в описи указаны авторы и названия мишь небольшой части книг из библиотеки Кальера. Ни одной книги кого-либо из авторов, близких к Пор-Роялю, среАи них нет.

18 Шарль-Пари Орлеанский граф де Сен-Поль герцог Ае Конгвиль (16491672) - сын герцогини Ае Лонгвиль от внебрачной связи с герцогом Ае ^арошфуко, был официально признан герцогом де Аонгвилем в качестве сына. Стал оАним из претендентов на польский престол, однако был убит во время военной кампании в Гоммандии.

19 Речь илет в первую очередь о Шарле-Эммануиле II герцоге Савойском (1634-1675), его сестре Генриетте-ААелаиле Савойской, курфюрстине Баварии (1636-1676), второй жене - Марии-Жанне-Батисте Немурской (1644-1724) и супруге его племянника - Олимпии Манчини, графине де Суассон (1639-1715).

20 Наиболее влиятельными среди них были упомянутый выше герцог Ае Шеврёз и герцог Ае Бовилье (1648-1714), женатые на Аочерях могущественного министра АюАовика XIV. 
штын ${ }^{21}$, маркиза д’Юксель 22 . Однако целью Кальера была служба королю и статус «государственного человека», а не клиента влиятельного вельможи. В конечном счете, многочисленные усилия увенчались успехом. Пиком этой карьеры стало участие Кальера в заключении Рисвикского мира в качестве чрезвычайного и полномочного посла короля Франции. По результатам переговоров он был щедро вознагражден и в довершение всего стал личным секретарем Людовика XIV, имеющим право подписывать письма от имени короля. Именно как дипломат, участвовавший в этих важных переговорах, Кальер и известен историкам более всего. Впоследствии он суммировал свой опыт в работе по искусству дипломатии «Как договариваться с государями», которая вышла в 1716 г., уже в XVIII веке была переведена на разные языки, включая русский ${ }^{23}$, и стала одним из классических трудов по ведению переговоров.

Этот дипломатический опыт и его осмысление оказывается крайне важным в контексте данного исследования, поскольку язык, речь является основным инструментом дипломата. Даже в более ранних работах Кальера очень хорошо ощущается эта идея влиятельности произносимых слов, и их способности не только выражать, но и, вольно или невольно,

21 Ян АнАжей Морштын (1621-1693) - польский Аворянин и политик, с 1668 г. казначей (подскарбий великий коронный). Кальер завязал с ним близкие отношения во время своей первой польской миссии и с тех пор постоянно их подАерживал. В 1683 г. Морштын эмигрирова^ во Францию и прожил там последние годы. Благодаря посредничеству Кальера, его сын женился на Аочери герцога де Шеврёза.

22 Мари Ае Байоль, вдова маркиза А'Юксель (1626-1712) - близкая подруга герцогини Ае Лонгвиль. Известна своим салоном, в котором обсужАались политические новости со всей Европы и перепиской с наиболее влиятельными вельможами.

23 Камиер. 1772. Это единственное сочинение Кальера, переведенное на русский язык. Существует его современное издание: Кальер. 2000. 
формировать некоторую реальность, в первую очередь, провоцируя ту или иную реакцию собеседника. С другой стороны, с опытом дипломата связано и подчеркивание важности слушания, которое у Кальера, в отличие от риторической традиции понимается как активное действие, позволяющее узнать много больше, чем собеседник намеревается сказать, если внимательно отнестись к подбору слов, оговоркам, интонациям, жестам и т.п.

Идею о влиятельности публично высказываемых слов Кальер неоднократно проверял на практике. По примеру своего отца он сделал литературную деятельность инструментом политического влияния. С самого начала он очень серьезно относится к ней как к жизненной стратегии, позволяющей польстить нужным людям и способствовать устройству или возобновлению своей карьеры. Первый опус Кальера о логике любви имел посвящение тому самому графу де Сен-Поль, помощь которому положит начало его дипломатической карьере. В период, казалось бы, полного ее краха Кальер прилагает немалые усилия, чтобы произвести благоприятное впечатление на монарха, а равным образом завоевать статус уважаемого литератора. В начале 1687 года он пишет и печатает частное издание эпистолы на выздоровление Людовика XIV от анальной фистулы и похвалы Дофине (племяннице его бывшего покровителя герцога Савойского), которые были представлены им в Версале. Летом того же года он получает привилегию на издание «Поэтической истории недавно разразившейся войны между Древними и Новыми» и уже осенью издает эту поэму, в которой занимает нейтральную позицию, воздавая честь и аргументам, и заслугам «древних», и достоинствам 
«новых»24. Наконец весной 1688 г. Кальер публикует «Панегирик Людовику XIV» и получает право прочесть его перед академиками. Результатом всех этих маневров (конечно, не без дополнительной поддержки) становится то, что после смерти Филиппа Кено в конце 1688 г. Французская академия предлагает кандидатуру Кальера на вакантное место, и в начале 1689 г. после одобрения короля он был единогласно избран академиком.

Как считается, как раз отрабатывая свой статус академика, Кальер и пишет три работы о хороших и дурных манерах речи ${ }^{25}$, которые послужили основой для еще одной работы о знании света, которая выходит уже перед его смертью в 1717 г. Однако, можно сказать и иначе - Кальер пользуется статусом академика, публикуя эти книги. Дело в том, что их выход совпадает по времени с обретением нового покровителя в лице герцога де Шеврёза, который (наряду с королем и прежними покровителями Кальера) восхваляется в тексте. Результатом же различных усилий Кальера и помощи де Шеврёза в этот период становится статус посла на переговорах в Рисвике.

В данном исследовании нас будут в наибольшей степени интересовать две из этих работ, непосредственно связанные с вопросами языка и социальных иерархий. Первая книга,

24 Считается, что знаменитый спор “о Аревних и новых" берет свое начало 27 января 1687 г., когАа Шарль Перро выступил во Французской акалемии с поэмой "Век Аюдовика XIV", восхвалявшей монарха и современные науки и искусства.

25 В 1695 г. вышла еще одна книга - "Об остроумии" (Callières. 1695). Она была издана анонимно, и авторство Кальера до сих пор остается предметом Аискуссий. Убедительные Аоводы в пользу Кальера были приведены Арнальдо Пиццоруссо: Pizzorusso. 1968. Учитывая эти аргументы и очевидное сходство многих тезисов с теми, что обнаруживаются в анализируемых нами текстах, в Аанной статье трактат об остроумии также будут использован как произведение Кальера. 
опубликованная в 1692 году, называется «0 модных словах и новой манере говорить» и посвящена она преимущественно критике вычурной речи придворных. Вторая, выпущенная в 1693 году как продолжение, именовалась «0 хороших и дурных обычаях в манере речи» и была сфокусирована на речи горожан. Оба текста имели успех у публики, в особенности первая, тираж которой был раскуплен в течение месяца 26. Традиционно считается, что основной читательской аудиторией этих работ, как и всех подобных текстов, наставляющих, как правильно себя вести в приличном обществе, была буржуазия и провинциальное дворянство. Однако, учитывая писательские стратегии Кальера, а также то, что уже в XVIII столетии он приобрел славу грамматика и знатока языка, можно предположить, что в действительности и литераторы, и придворные не обошли их своим вниманием. Д’Аламбер написал похвалу Кальеру, сказав немало лестных слов о его исследовании языка,27 Луи Морери посвятил ему отдельную статью в своем «Большом историческом словаре» 28 , а аббат Гуже уделил внимание его трудам в своей «Французской библиотеке, или Истории французской литературы»:

правияа и рассуждения господина Ае Кальера тем более заслуживают быть выслушанными, что он не только размышлял о сущности гения подлинного красноречия, но к тому же был восхваляем Французской академией, как писатель, который сам был весьма красноречив ${ }^{29}$.

Тексты имеют схожую структуру, они представлены как огромные письма, внутри которых подробнейшим образом

26 В Аанной работе будет использоваться третье издание книги, сделанное в 1693 г. и существенно Аополненное.

27 D'Alembert. 1967: 511-513.

28 Moreri. 1759: III. 65.

29 Goujet. 1756: I. 495. 


\section{Стогова А.В. Запах слов}

пересказываются беседы о манере речи, имевшие место в доме знатной дамы. «Письмо» в первой книге представлено максимально достоверно: оно имеет точную дату 14 января 1692 г. и отсылку к визиту Людовика XIV в Фонтенбло в сентябре 1691 г., в котором его сопровождал английский король в изгнании Яков II с супругой. Это имело немаловажное значение, поскольку многие обсуждаемые выражения в речи придворных непосредственно связаны с приемом, устроенном французским королем. В силу этого текст становится суперактуальным и подчеркивает ситуативность и изменчивость языка, а сама речь оказывается теснейшим образом связана с событийной и материальной составляющими жизни. Письмо во второй книге, где обсуждается манера речи горожан, уже не имеет никаких временных свидетельств. Известно только, что пересказываемая беседа имела место после выхода книги «0 модных словах». Учитывая крайне небольшой промежуток между изданием первого и второго текстов, новые рассуждения также оказываются очень актуальными.

Поскольку «письма» пересказывают беседы, то основная часть текста построена как полилог, в которых разговор выстроен вокруг обсуждения конкретных неверно употребляемых слов и выражений, на примере которых разбираются разного рода речевые ошибки, связанные и с подбором слов, и с их произношением, и с их уместностью. Беседы ведут люди высокого положения, бывающие при дворе. Но Кальер не ограничивается формальными характеристиками, маркирующими их статус, и дает о каждом некоторую информацию, которая позволяет понять манеру поведения персонажа в ходе беседы и его отношение к обсуждаемым оборотам речи. Разговор о манере общения придворных ведут: хозяйка дома - Дама весьма почтенного возраста (qui est déja sur le retour); Герцогиня и Маркиза - напротив, молодые и привлека- 
тельные; молодой Герцог, исправно посещающий двор (qui est un courtisan fort assidu), и молодой Граф, которого война привлекает больше, чем придворная жизнь; а также Командор, который является кузеном хозяйки и недавно вернулся с Мальты после почти двадцатилетнего отсутствия при дворе, чтобы служить королю ${ }^{30}$.

Вторую беседу о горожанах продолжают вести Дамахозяйка, Маркиза, Герцог и Командор, а вместо Графа и Герцогини к ним присоединяется Аббат «из почтенного парижского семейства, и из числа тех священников, что любят ухаживать за дамами». ${ }^{31}$ Также на время в разговор включается пришедший с визитом господин Тибо (единственный, чье имя можно не скрывать в печатном издании) - сын буржуа из числа «друзей» хозяйки, то есть «тех богачей, чья дружба нередко бывает полезна знатным особам, нуждающимся в деньгах».32 Этому персонажу - временному, но олицетворяющему собой всех тех буржуа, чья речь подвергается осуждению, дается наиболее подробная характеристика. Это не просто сын богатых буржуа, но молодой человек, стремящийся поступить на службу и получивший образование, однако нуждающийся (по мнению собравшихся) в избавлении (d'être purgé) от буржуазной манеры речи. 33

Все эти характеристики не случайны, они оказываются важны, поскольку выявление недостатков чужой речи всегда представлено как результат телесного присутствия и описывается в первую очередь как аудиальный опыт. С такой позиции рассмотрения речевая коммуникация предстает не

30 Callières. 1693a: 3-4.

31 Callières. 1693b: 2.

32 Callières. 1693b: 15.

33 Callières. 1693b: 15. 


\section{Стогова А.В. Запах слов}

только как акт сенсорного воздействия на слушателя, порождающего определенные эмоции, но и результат активного слушания - усилий слушающего, связанных с тем, чтобы с одной стороны не упустить из поля зрения этот чувственный опыт, который может показаться на первый взгляд не имеющим значения в сравнении с рационально воспринимаемым содержанием разговора, а с другой - осмыслить его и контролировать свои эмоции. Для Кальера важны обе позиции - и страсти, и контролирующий их (и манипулирующий ими) разум. Эта идея манипуляции чувствами другого, намеренного воздействия на страсти, которые управляют большинством людей, которую позднее он будет описывать как один из методов дипломатии, лежит в самой основе данных книг. Рассуждая преимущественно о речи устной, Кальер не забывает и о том, что письменная речь, то есть любой текст, точно также может оказывать сенсорное воздействие дополняющее суть передаваемых в словах идей, но уже не на слух, а на зрение и пользуется этим, чтобы «обработать» своего читателя так же, как это делает дипломат.

Дело в том, что в работах Кальера можно выделить три уровня чувственного влияния языка. Во-первых, слова и манера речи, вызывающие отвращение - предмет обсуждения и осуждения участников полилога. Обе книги представляют собой последовательный разбор выражений, которые встречаются в речи, соответственно, придворных и горожан, с определением их недостатков и поиском достойной альтернативы.

Второй уровень - это речь самих участников беседы. В подавляющем большинстве случаев обсуждается не просто отвлеченная манера говорить, а манера речи кого-то из присутствующих. Но в этом обсуждении обнаруживается, что любая речь, даже безупречная с точки зрения языка и логи- 
ки может оказывать очень сильное эмоциональное воздействие и вызывать самую разнообразную реакцию. Наиболее обстоятельно описывается опыт молодого буржуа господина Тибо, в присутствии которого обсуждают дурную речь горожан. Кальер описывает, как его в этой ситуации раздирают разнообразные чувства, и под их влиянием он вмешивается в беседу, в свою очередь, вызывая своими словами негодование хозяйки дома:

Тем временем господин Тибо испытывал страдания (la nature patissoit en Monsieur Thibault), выслушивая эту критику Аурной манеры речи ^юдей своего положения. Он ощущал укоры совести за то, что совершил многие из тех ошибок в манере говорить, осужАение которых услышал, но при этом был слишком раздосадован, чтобы извлечь урок из беседы, которая могла бы быть ему столь полезна наставлениями и указанием на ошибки. И поА влиянием той дурной гордыни, которая, которая почти неистребима в человеческом сердце, и которой сердце богатого буржуа чаще отАается во власть, нежели сердце знатного человека, он с трудом выносил осуждение речи горожан и мечтал поскорее уйти, чтобы избавить себя от этой муки. Но он смущался и стыАился того, что сказал о даме из "Модных слов" и, поняв из последующей бесеАы, что Аама и Командор, которых он вилел переА собой, и были главными персонажами этой книги, он не решался более говорить, но все же хотел исправить промах, который допустил, назвав старой знатную Ааму, к которой испытыва^ большое уважение и наА которой вовсе не хотел насмехаться подобным образом. Пребывая в подобном замешательстве, он повел себя как буржуа, ничего не смыслящий в правилах поведения, и вместо того, чтобы извлечь выгоду из критики Аамы и оставить в прошлом обилу, которую нанес ей, сам того не желая, он некстати напомни^ о ней, сказав при прощании такие слова: “Прошу меня извинить, маАам, если обилел вас, говоря о даме, которая критикует горожан в книге о модных словах. Я Аумал, вы не придадите им никакого значения, а если бы знал, то никогАа не употребил бы слово “пожилая", которое так вас расстроило". Это извинение бы^о принято Аамой столь же плохо, сколь и невольно Аанная характеристика ее как старухи. Она покраснела от гнева и жестоко и 


\section{Стогова А.В. Запах слов}

презрительно ответила ему: “ИАите, илите, господин Тибо! На некоторых ююдей даже не приходит в голову обижаться"34.

Столь подробное описание переживаний не просто подчеркивает значимость правильно подобранных слов и в целом умения контролировать свою речь и поступки. Для Кальера в обеих книгах оказывается важным создать образ беседы не только как обмена мыслями, но как серии последовательных или одновременных эмоциональных состояний, которые спровоцированы услышанным и которые в свою очередь могут порождать ответные реплики.

Наконец слова составляют ткань текста, обращенного к читателю, и здесь оказывается важным визуальное восприятие речи в процессе чтения. Дурные, неправильные слова присутствуют в тексте и как обсуждаемые в ходе беседы, и как произносимые ее участниками. Эти выражения всегда выделены курсивом, чтобы они бросались в глаза точно так же, как они должны резать слух. Этот визуальный опыт должен пробудить в читателе воспоминания о его собственной или чужой речи, об опыте говорения или слушания. Чтение уподобляется слушанию через аналогичный эффект слов: в зависимости от того, обладает ли читатель «разумом и вкусом», текст, как отмечает Кальер в предуведомлении, должен либо порадовать и развеселить, либо «задеть его самым чувствительным образом»,35 точно также как это произошло бы в устной беседе. Во втором тексте, посвященном хорошим и дурным манерам речи, это внимание к визуальным аспектам восприятия речи усиливается, когда предметом рассмотрения оказываются не устные выражения, а формы выражения любезности, используемые в частной переписке.

34 Callières. 1693b: 106-110.

35 Callières. 1693a: [V]. 
Таким образом, принципиальной основой всех рассуждений Кальера оказывается акцентирование значимости чувственного опыта в человеческом общении, порождающего эмоциональные реакции, которые именно в силу этого колоссального значения должны анализироваться и контролироваться разумом. В своей последней работе, посвященной правильным манерам общения при дворе, Кальер связывает этот сенсорный опыт общения как с правильным употреблением и произношением слов, так и с интонацией, с которой они произносятся - «музыкой выражения чувств» ${ }^{36}$. Он также добавляет, что не менее важным оказывается выражение лица и особенно глаз, которое не должно противоречить тому, что произносится вслух ${ }^{37}$.

Идеал приятной беседы и «человека достойного» (honnête homme), о которых к концу XVII века было написано уже изрядное количество книг, преломляются у него в контексте традиции рассуждений о страстях. Поскольку Кальер вообще практически не дает отсылок к другим авторам, вопрос о непосредственном влиянии эмпиризма и рассуждений Декарта пока остается открытым, однако очевидно, что, по меньшей мере в общих чертах, с идеями Декарта автор был знаком ${ }^{38}$. И в то же время, общая интенция рассуждения о

36 Callières. 1717: 63.

37 Callières. 1717: 64.

38 Из посмертной описи имущества Кальера известно о его интересе к Локку, но к 1692-1693 гг. на французском языке были известны только рассуждения Локка о гражданском правлении, изданные в 1691 г. в ГомланАии. В той же описи упоминается портрет Аекарта (наряау с Гассенди), что можно расценивать как свидетельство уважения и интереса к его взгяяАам (Collection de documents. 1885: 142). Вне всяких сомнений, на картезианскую концепцию страстей опирается Аругое сочинение - "Об остроумии", которое также приписывается Кальеру. В нем всячески подчеркивается значимость и польза "страстей", но только при непременном условии обуздания их разумом. Основываясь на этом тексте, Филипп Шомети 
страстях в его текстах оказывается очень близка к янсенистской критике. В последнем своем сочинении, посвященном «знанию света», Кальер выдвигает два основных тезиса, обосновывающих важность хороших манер (в числе которых он рассуждает и о речи). Один из них заключается в том, что «проще сформировать суждение, основываясь на том, что поражает наши чувства, нежели пользуясь светом разума»,39 а потому впечатление, произведенное на уровне чувств, оказывается очень важным, а иногда и доминирующим фактором в формирующейся оценке человека. Другой отсылает к тому, что в людях доминируют суетность и тщеславие, и если не удовлетворить их приятными манерами и сладкими речами, то даже благое дело может пропасть втуне, а если говорить грубо и свысока, легко навлечь на себя гнев и ненависть ${ }^{40}$.

Уже приведенное выше описание терзаний господина Тибо показывает, насколько прочно идеал поведения, транслируемый Кальером, увязывается с умением не только контролировать страсти, но и извлекать из них пользу. Впоследствии он разовьет эту мысль несколько в иной плоскости, рассуждая о том, что хорошие манеры и приятные речи наиболее простой способ не только создать и поддержать хорошую репутацию, но и «проникнуть в сердца людей», которые чем-то важны (т.е., по сути, манипулировать ими). ${ }^{41}$

Авторитетная позиция в обоих текстах озвучивается от имени Командора, который вернулся с Мальты после длительного отсутствия, чтобы служить своему королю, и в силу

называет Кальера "картезианцем и последователем Мальбранша". Chométy. 2006: 57 (note 3).

39 Callières. 1717: 11-12.

40 Callières. 1717: 12.

41 Callières. 1717: 16. 
этого опыта оказывается восприимчив к изменениям, произошедшим в языке. Именно его позиция может быть охарактеризована как рационалистическая и прагматическая, осуждающая неразумность, невежественность, аффектацию и т.п. как неспособность или нежелание действовать разумно - то есть, с позиции идеала человека, руководствующегося разумом ${ }^{42}$, и, с другой стороны, как нарушение порядка, свойственного самому устройству языка, когда необдуманное употребление слов приводит к тому, что люди «калечат наш язык, говоря совсем не то, что хотят выразить» 43 (например, употребление эпитета «большой» (gros) по отношению к человеку, когда имеется в виду вовсе не его рост и комплекция, а величие, несмотря на то, что в языке есть подходящее для этого случая прилагательное grand). В данном случае, опять же без прямых отсылок, Кальер следует идеям «Общей и рациональной грамматики» Антуана Арно и Клода Лансло о том, что стихийно складывающиеся языковые обычаи нуждаются в рациональном воздействии и корректировке. Тезис грамматиков Пор-Рояля, о том, что «следует не только уметь владеть речью, но и проникать в ее основания, дабы действовать в соответствии с наукой там, где иные действуют лишь по заведенному обычаю», ${ }^{44}$ превращается у Кальера в императив поведения людей, «обладающих разумом и вкусом».

В отличие от авторов грамматики, его интересует язык не столько сам по себе, сколько как критерий, по которому

42 При этом даже командор не представлен у Кальера как бесстрастный критик. Речь молодых собеседников и их отношение к языку вызывают у него "безудержную печаль, которую он не смог бы скрыть, если бы не находился в обществе этих Аостойных ценителей остроумия". Callières. 1693a: 20.

43 Callières. 1693a: 23.

44 Арно, Аансло. 1990: 70. 
можно оценивать говорящего. Давая пояснения по каждому из неудачных примеров манеры выражаться, Командор добавляет рассуждения и о языке, и обществе в целом, проводя параллели между языковым и социальным порядками. Чужая речь, вызывающая чувственную и эмоциональную реакцию, пронизывающую оба текста, - это речь не только и не столько конкретных людей, сколько определенных социальных групп, о чем свидетельствует и проблематика рассматриваемых нами текстов: один из них посвящен манере речи придворных, другой - речевым особенностям, свойственным буржуа. Так что в значительной мере разговор о манерах речи это разговор о социальных иерархиях и о том, насколько язык способен выстраивать эти иерархии и свидетельствовать о них. И, в конечном счете, все это помогает Кальеру обрисовать идеальный образ человека. В этом отношении для него оказывается важным, что и сам язык имеет свои иерархии: в нем выделяются возвышенные и низкие, грубые слова и выражения, устаревшие, устоявшиеся или новомодные, варварские (даже «готические ${ }^{45}$ ») и «светские». Эта иерархия слов непосредственно связана со статусом людей, которые их употребляют.

В первую очередь речь идет о властной иерархии, в которой только монарх обладает абсолютным суверенитетом и вправе устанавливать систему отличий для подданных, в том числе на вербальном уровне. Одним из примеров этого оказываются надписи, сделанные по королевскому велению на дверях помещений, выделенных в королевском дворце для проживания придворных, в которых язык становится способом конструирования иерархии. На дверях комнат, предназначенных для особ королевской крови, писалось

45 Callières. 1693b: 206. 
«для господина...», на дверях комнат всех прочих, включая герцогов и высших сановников, просто «господин...».46 Никто кроме суверена не имеет такого права конструировать иерархические отличия, даже знатное происхождение (за исключением наследников престола) «не дает власти над теми, кто не столь благороден» ${ }^{47}$. Подданные, соответственно не равны между собой только по воле суверена, а значит не должны кичиться положением и требовать или вводить самим дополнительные знаки отличия с одной стороны и обязаны соблюдать установленный порядок - с другой. Поскольку подлинная власть, как утверждает Кальер, держится на любви и уважении, любезность (которая, в отличие от грубости не подчеркивает социальные отличия, а затушевывает их) рассматривается как всеобщая обязанность, закон, которому все обязаны подчиняться в равной мере, а «удовольствие», порождаемое таким общением, является одной из составляющих социальной гармонии и мира 48 . Это удовольствие и описывается как чувственная реакция на окружающих людей, включающая слуховые, визуальные, ольфакторные и тактильные ощущения, в силу чего рассуждения о правильной манере речи то и дело дополняются характеристиками внешнего вида или манер собеседников.

Монарх (правильный монарх, коим и является Людовик XIV) - это образец мудрости, любезности и умения держать себя в руках, что является основой счастливого, справедливо-

46 Callières. 1693b: 183.

47 Callières. 1693a: 157.

48 Кальер противопоставляет страдание, которые испытывают люди, с которым обходятся неуважительно и нелюбезно, и ненависть, которую они выражают в ответ, удовольствию взаимного уважения. Callières. 1693а: 158-159. 
го правления ${ }^{4}$. Он стоит на вершине не только властной, социальной и человеческой иерархий, но и «речевой»: он - воплощение того идеала речевого поведения, который рисует Кальер и который должен быть образцом для подражания. Но и остальные должны соблюдать законы любезности, ибо их нарушение грозит не только страданиями и ненавистью, но и социальными беспорядками ${ }^{50}$. Кальер уподобляет дурную манеру речи болезни, другому чувственному опыту, отмечая, что, хотя от этой болезни и нельзя умереть, она доставляет массу страданий и от нее необходимо лечиться51. Подданные (в особенности придворные) «могли бы быть столь же великодушными благодетелями, как он [король - A.C.], такими же мягкими, обходительными, порядочными, благовоспитанными и любезными; они могли бы научиться искусству нравиться, говорить справедливо и правильно и произносить лишь то, что должно быть сказано по каждому вопросу, и у каждого вызывать уважение и любовь. И поскольку ничто не наставляет лучше, чем живой пример, пренебрежение всем этим тем менее простительно, что они не хотят извлечь пользы из великого преимущества жить во время счастливого правления столь превосходного короля». 52

Но разным социальным группам свойственны в этом плане свои ошибки или симптомы, и как уже было сказано,

49 Панегирик королю как "неиссякаемому источнику добродетелей и героических поступков" и образцу Аля подражания завершает рассуждения о "модных словах". Callières. 1693а: 233-239.

50 В работе о знании света Кальер посвящает целый разАел рассуждениям о порядке как основе всякого общества, в особенности "светского и приятного", и о необходимости подчинять свое поведение выполнению правил и обязанностей, ставя общее благо и интересы выше собственных. В чисмо общих благ в монархиях, безусловно, на первое место ставятся интересы суверена. См.: Callières. 1717: 121-130.

51 Callières. 1693b: 23-24.

52 Callières. 1693a: 240-241. 
рассматриваемые книг посвящены в первую очередь придворным и горожанам (буржуа). Если с разделением суверена и подданных у Кальера все очень четко и ясно (проблему тирании он практически обходит молчанием, предпочитая говорить о «правильном монархе»), 53 то в отношении иерархии среди подданных обнаруживается масса нюансов. Поскольку эта иерархия создается сувереном, она оказывается довольно подвижной. По мнению Кальера, иерархические различия, которые аристократы полагают своим неотъемлемым правом, таковыми не являются, это - лишь королевская признательность за заслуги предков, а значит, знатное происхождение может быть сопоставимо с такими достоинствами как ум, знания, добродетель и заслуги у человека незнатного происхождения, добившегося признательности короля54. И молодые аристократы должны без устали заниматься самосовершенствованием, чтобы подтвердить свое превосходство или, по меньшей мере, не позорить имя предков. С другой стороны, во втором диалоге рассуждения «О модных словах» довольно много внимания уделяется «фальшивым» дворянам и аристократам, придумавшим себе дворянский статус или титулы, то есть, незаконным и несправедливым образом присвоившим себе отличия, которые может даровать только монарх и только за определенные заслуги. При всем осуждении, которыми окрашены эти рассуждения, Кальер подчеркивает перформативную силу язы-

53 Практически единственное ограничение воли суверена, на которое обращает внимание автор, касается именно языка: монарх может изобрести новое слово, но не в силах его навязать к употреблению; публика всегАа сама решает, какое слово приживется, и потому очень важно, чтобы подАанные подходили к вопросам языка осмысленно и использовали те или иные выражения, только если они согласуются с разумом и законами кюбезности. Callières. 1693а: 135-137.

54 Callières. 1693a: 137-138. 


\section{Стогова А.В. Запах слов}

ка: хотя эти новоявленные аристократы и являются таковыми только в силу того, что именуют себя графами и маркизами, с их несправедливыми притязаниями приходится считаться, и в глазах общества они становятся титулованными особами. Подобная значимость речи в конструировании социальной реальности также оказывается выражена через эмоциональное восприятие: в случае, если именование (присвоение титула) исходит от короля, оно оказывается справедливым, полноправным и потому окрашенным позитивными эмоциями, в случае если то же самое осуществляют сами подданные, это не может не вызывать у окружающих негативных эмоций или насмешки (смехотворность подобных претензий подчеркивается именем одного из таких лже-дворян - господина де Журдена55). Все это лишь акцентирует важность внимательного и осторожного обращения со словами и, с другой стороны, положительные качества и заслуги другой пограничной группы людей, которые завоевывают или подтверждают свое положение не словами, а делами - «достойных людей, приносящих пользу Королю, каждый сообразно своим различным талантам»,56 и с них всем придворным стоило бы брать пример.

При всей проницаемости границы между различными социальными группами, отрицать различия между знатными людьми и буржуа не приходится, поскольку в целом их образ жизни и привычки очень сильно отличаются. Это касается и речи, а потому речь придворных и буржуа оказывает разное чувственное воздействие. Хотя Кальер подчеркивает, что и среди тех, и среди других есть разумные и здравомыслящие люди, которые умеют хорошо говорить, его

55 Господин де Журден - герой комедии Мольера "Мещанин во Аворянстве".

56 Callières. 1693a: 192. 
больше интересуют те, кто ошибаются, поскольку ошибаются они по-разному. В кругу придворных объектом критики становятся те, кто желает произвести сильное впечатление, выделиться, подчеркнуть свой статус и социальную дистанцию особой манерой поведения и речи ${ }^{57}$. Это те, кто кичится своим происхождением, но сами не имеют никаких заслуг. Они изобретают новые модные словечки, которые не согласуются со здравым смыслом и нормами языка, но отличают их от всех прочих. Их речь утомляет и ошеломляет слушателя, понять ее может только тот, кто сам вращается в этих кругах. С одной стороны разговор о несуразной речи придворных становится для Кальера основой для критики феномена моды, основанной на внешних эффектах и подражании, а значит, не задействующей разум и функционирующей только на уровне страстей 58 . Опыт беседы с щеголями, изобретающими причудливые выражения, оказывается тесно связан в пространстве текста с опытом ношения введенной ими же в моду несуразной одежды. Façons de parler59 уподобляются фасонам одежды. Эта аналогия также оказывается чувственной, ибо, придав костюму «форму и вид по своему вкусу, им обычно удается сделать его потрясающе неудоб-

57 Например: «Я знавала женщин, которые изрядно теряли привлекательности из-за того, что чрезмерно стараясь ее Аостичь неестественной манерой выражаться или произносить то, что они говорят", а “легкомысленные молодые ^юди, неразумные и мишенные вкуса, [ ...] убеждены, что жонглирование новыми словечками делает их бесконечно приятными и выАеляет среди остальной массы мюдей”. Callières. 1693a: 186-187.

58 В картезианской мингвистике вовлеченность разума является основой Аля Аругой иерархии: человека и животных. "Речь" животных вызвана только страстями и ограничена ими, а потому не является языком. Они не способны "говорить" ни о чем, кроме того, что обусловлено Аавлеющей в Аанный момент страстью. Хомский. 2005: 25-28.

59 Манера речи. 
ным».60 Выражения, противоречащие логике и строению языка и используемые лишь для того, чтобы произвести впечатление и продемонстрировать «модный» статус, представлены столь же неудобными в использовании, как и ношение огромных рукавов, составленных из «многоэтажных» складок ткани. Мода и слова у таких людей оказываются неразрывно связаны в своей бессмысленности:

- Раз уж мы говорим об изобретениях в отношении моды, так же, как и в отношении новых слов, сказал Герцог, знает ли госпоАин Командор, что такое falbala61?

- Нет, ответил Командор.

- Un falbala, - продолжил Герцог, - это широкая мента из плиссированной ткани, которую женщины прикрепляют вокруг подола своих юбок.

- Несомненно, заметил Командор, это название это название ей дал какой-нибудь турецкий или армянский купец, позаимствовав из своего языка, также как мы зовем софой (sofa) тот преАмет мебели, благоАаря которому можно возлежать на турецкий манер.

- Вовсе нет, сказал Герцог, уверяю вас, что придворный, обогативший наш язык прекрасным словом falbala, совсем не сведущ в восточных языках.

- Налеюсь, он сведущ в чем-нибудь более полезном, ответил Командор. Но мне кажется, что если уж так хочется изобрести новое слово, нужно, чтобы оно хоть как-то было связано с тем преАметом, который обозначает. 62

С другой стороны желание произвести эффект и подчеркнуть собственную исключительность нередко приводит к тому, что придворные позволяют себе быть нелюбезными, на словах постоянно подчеркивая превосходство своего статуса (даже если на самом деле он не так уж и высок) и, также

60 Callières. 1693a: 197.

61 В Аанном случае обыгрываются два значения слова falbala. Так называют не только оборку или волан, но и ююбую пышную и безвкусную отделку, каковой оказывается и само слово.

62 Callières. 1693a: 200-201. 
на вербальном уровне, лишая должного уважения других. Опыт общения с такими придворными описывается как опыт чувственный. Их манера речи не только утомляет, от нее бросает в жар, она взывает отвращение и гнев. Причем, как уже отмечалось слуховой опыт неразрывно связан с визуальным, тактильным и ольфакторным, и обсуждение грубой, невоспитанной речи то и дело сопровождается негодованием относительно столь же отталкивающих манер и внешнего вида молодых дворян,

[которые] приходят к нам с табакеркой в руке, с лицом и пальцами, запачканными табаком, который они то и дело суют и нам в нос, и остальным, осыпая свои отвратительные усы табаком цвета золы из камина, который пачкает им лицо, как трубочистам; откуда табак падает на их галстуки, на их парики, на их одежду в таких количествах, что при малейшем Авижении они заставляют чихать всех присутствующих в комнате, становясь живой табакеркой в ^юбом месте, куАа приходят, что придает им неопрятный и невежливый виА 63 .

Опыт слушания нелюбезных, двусмысленных, насмешливых речей встраивается в этот общий чувственный опыт общения, неучтивая манера разговора оказывается столь же невыносима, и одна из дам, участниц беседы, замечает, насколько неприятно подвергаться [буквально: être exposé A.C.] «визитам столь невоспитанных людей, которые сначала утомляют любезностями дурного вкуса и неприличными разговорами, а затем уходят, не сказав никакой учтивости»64. Эта связь выстраивается за счет особого построения нарратива, в котором дурная речь постоянно оказывается в числе «других невежливых манер обхождения», но при этом сама речь, описывающая этот негативный опыт, тоже должна вы-

63 Callières. 1693a: 70-71.

64 Callières. 1693a: 76. 


\section{Стогова А.В. Запах слов}

зывать у читателя отторжение своей аффектированной неправильностью:

...они Запрокидывают ноги на сосеАнее сиденье или на ручку кресла, в котором сияят, скрещивают их или придают им еще бомее непристойное положение, полагая, что это сообщает им виА благородства (l'air de qualité), и, вместо того, чтобы сказать нам что-нибудь любезное или приятное, ежедневно оглушают нас дурным исполнением оперных арий. Признаюсь вам, что мне это Ао смерти надоело, меня кидает в страшный жар! (me donne des vapeurs horribles). 65

Если придворные делают все это намеренно, желая действительно ошеломить своей речью и манерами, воздействуя на чувства больше, чем на разум, то языковые прегрешения горожан происходят от их невежества и привычки к грубому образу жизни, которая ставит их вне моды66. То и дело отмечая размытость социальных границ, Кальер, как и многие другие авторы литературы о манерах поведения, одновременно занимается их конструированием. В данном случае, постоянное описание горожан как грубых и не знающих тонкостей языка и общения оказывается крайне важной характеристикой, поскольку речь идет вовсе не о простонародье. Из первой части текста «0 хороших и дурных манерах речи», где описываются те или иные случаи общения участников беседы с горожанами, становится очевидным, что основным объектом критики оказываются весьма зажиточные буржуа, стремящиеся вести «модный» образ жизни. Они устраивают обеды с изысканными блюдами, но не умеют вежливо пригласить в гости, уставляют камины фарфором, но неправильно произносят это слово,

65 Callières. 1693a: $72-73$.

66 Свидетельством тому оказывается использование горожанами множества слов и форм, которые расцениваются как устаревшие, например, appris или possible. Callières. 1693b: 147, 149. 
заказывают портреты Гиацинту Риго 67 , но не знают, как элегантно об этом рассказать. Оба героя этой книги, которые оказываются образчиками нечувствительности к хорошей манере речи, - Аббат и господин Тибо - представляют столичную буржуазную элиту. Таким образом, внешнее копирование образа жизни, которое становится доступным для буржуазии на материальном уровне, противопоставляется манерам поведения, с которыми они незнакомы или знакомы крайне плохо и не понимают их сути, опять же лишь копируя фразы и жесты, используя их неверно и не к месту. Эти самые манеры оказываются менее очевидным, но более надежным маркером социальных отличий. Соответственно, те горожане, которые умеют говорить и хорошо себя вести, оказываются достойны положения, на которое претендуют, а придворные, которые этого не умеют, теряют право на превосходство 68 .

«Дурная» речь буржуа также ощущается неотрывно от внешнего вида и вызывающих неприятие манер и противопоставляется манере говорить придворных ${ }^{69}$. Кальер, объяс-

67 Гиацинт Риго (1659-1743) - французский художник, мастер парадного портрета. ^юбопытно, что Кальер упоминает именно это имя, поскольку Риго стал востребован в Версале только в 1688 г., а Ао этого времени был очень популярен именно у третьего сословия.

68 "Аействительно множество горожан говорят не хуже придворных; и когАа мы обращаем внимание на хорошие и дурные обычаи в манере речи и в умении поместить каждое слово на подобающее ему место, мы вовсе не претендуем на то, что это хорошо умеют Аелать только приАворные; и в столице и в провинции есть множество мюдей, которые ни в чем тут не уступят придворным, и точно также есть немало придворных, которые говорят Аурно, как простолюдины". Callières. 1693b: 63-64.

69 Особо выделяются совсем вопиющие случаи, когАа "мятежные буржуа" перенимают описанную выше манеру поведения придворных, забывая социальную Аистанцию и чувствуя себя "как Аома". Но хотя они ведут себя в точности как молодые придворные "закидывая ноги на сосеАнее сидение" и называя всех вокруг по фамилии, не Аобавляя "господин", это оценивается как фамильярность, а не эпатаж. Callières. 1693a: 152-153. 


\section{Стогова А.В. Запах слов}

няя различия между манерами речи придворных и горожан, и неспособность последних заметить недостатки своей речи, уподобляет речь запаху:

также происходят и с мюАьми, от которых дурно пахнет. Они не замечают своего смрада, потому, что привыкли к нему. Точно так же его не замечают и те, кто живет с ними рядом. ${ }^{70}$

В силу этого, никакое копирование образа жизни придворных (саму идею копирования Кальер всячески осуждает) не становится эффективным, а речь и манеры буржуа обнаруживают их «исконный» грубый образ жизни. Но, кроме того, аналогии, которые проводит Кальер, подчеркивают и аффективную, иррациональную природу вкуса ${ }^{71}$, которого лишены буржуа, не способные прочувствовать стиль жизни и речи и ограничивающиеся формальным заимствованием.

Если говоря о придворных, Кальер использовал чувственные образы, демонстрируя в первую очередь эффект их речи (т.е. то самое, на что она и была рассчитана), то в описании речи буржуа, которая «коробит утонченный слух [дословно - деликатные уши: écorche les oreilles delicattes A.C.]», ${ }^{72}$ к которым «уши не могут привыкнуть» ${ }^{73}$, в дополнение к этому эффекту появляются аналогии с их образом жизни вне светского общества, отсылающие к различным чувственным опытам. К примеру, манера речи человека, подвизающегося при дворе, которая выдает в нем жителя буржуазных кварталов, описывается через сопоставление со вкусом терруарных вин, ${ }^{74}$ а несходство речи «тех, кто прене-

70 Callières. 1693b: 143.

71 Об этом см.: Dens. 1981: 87.

72 Callières. 1693b: 213.

73 Callières. 1693b: 150.

74 То есть таких вин, во вкусе которых явно различаются черты, свойственные винам с этой территории. Callières. 1693b: 166. 
брегает изучением красот и тонкостей своего родного языка, и тех, кто с ними знаком и умеет хорошо говорить» делается более очевидным через сравнение с живописью. Это различие подобно разительным отличиям «между пачкуном, малюющим вывески для кабаков, и превосходным художником». Причем, интересным оказывается его пояснение:

у них одинаковые представления о вещах, которые преАстают их взору, и они нередко изображают оАни и те же объекты - человека, ^ошадь, Аерево, Аворец, с той лишь разницей, что хороший хуАожник рисует преАметы в точности такими, какими они являются на самом деле, тогАа как мазияа способен передать их образ мишь очень грубо и нечетко, поскольку не умеет рисовать ничего мучше уродливых, Аалеких от совершенства фигур. ${ }^{75}$

И, наконец, третья иерархия, которой на первый взгляд уделено меньше внимания, но которая, тем не менее, постоянно присутствует в тексте - это иерархия гендерная. В отличие от сословных отличий, гендерные эксплицитно проговариваются лишь однажды: им посвящена небольшая часть второй беседы о манере речи горожан, что само по себе показательно. Аналогии между женщинами (в первую очередь знатными, такими как участницы беседы) и буржуа построены на отсутствии у тех и у других соответствующего образования, позволяющего им знать и понимать строение языка. Кальер соглашается с тем, что «женщина высокого положения может легко обойтись без некоторых наук, которые более подобают мужчине, и даже если она с ними знакома, ей не пристало хвалиться этим, но, напротив, следует, как говориться, держать это в секрете, в кругу близких друзей, которые не посмотрят на это дурно» 76 . Но в то же время он подчеркивает, что «не стоит слишком подчеркивать свое

75 Callières. 1693b: 211-212.

76 Callières. 1693b: 125-126. 


\section{Стогова А.В. Запах слов}

невежество»,77 и, более того, некоторые знания женщинам совершенно необходимы, и в их числе выделяются те, что позволяют грамотно писать и говорить. Как отмечает Маркиза, занимаясь женским воспитанием обычно «не учат таким важным вещам, хотя прилагают столько усилий, чтобы научить танцевать. А ведь танцуем мы лишь от случая к случаю, тогда как разговариваем каждый день. Более того, добавила она со смехом, нас упрекают в том, что мы делаем это слишком часто». ${ }^{78}$ Действительно, разговор об особенностях женской речи заходит лишь тогда, когда начинают обсуждаться грамматические ошибки, вызванные незнанием основ языка, хотя на протяжении всей первой книги, посвященной речи придворных, женщины были одними из основных приверженцев вычурной манеры речи, раскритикованной Командором.

С другой стороны, женщинам свойственны те же слабости, что и придворным, с одним существенным отличием: мужчины-придворные не хотят пользоваться разумом, женщины не делают этого в силу своей природы. Эта позиция усиливается вполне традиционным для назидательных сочинений тезисом о чувственной природе женщин и о том, что образованная и приученная пользоваться своим умом женщина «менее склонна к грехопадению, нежели невежественная, которой ведом лишь зов испорченной натуры».79 В рассуждении «Об остроумии» Кальер более эксплицитно связывает эту особенность не с отсутствием должного образования, а с самой природой женщин и строением их орга-

77 Callières. 1693b: 126.

78 Callières. 1693b: 124-125.

79 Callières. 1693b: 129. 
низма, которые делают их «рабами всего чувственного».80 B силу этого, женщины являются «верными судьями моды и хороших манер, но имеют вкус только ко тому, что с этим связано». Всецело отдаваясь своему увлечению, то есть действуя неразумно, они становятся заложницами моды, «любая новая манера говорить, любые модные словечки настолько очаровывают их, что они готовы аплодировать любому, кто их употребляет».81

Кальер обращает внимание не столько на речь женщины, которая сочетает недостатки речи придворных и буржуа, сколько на то, как женщины слушают и воспринимают чужую речь, делая их пассивными участницами общения, невзирая на признанную любовь к болтовне. Подавляющая часть тех чувственных характеристик чужой речи, которые до сих пор были предметом нашего рассмотрения, даны в тексте именно женщинами. Их осуждение чужой манеры говорить - это осуждение преимущественно эмоциональное: она невыносима, утомительна, омерзительна, вызывает жар и так далее. И в третьей книге, посвященной шуткам и насмешкам ${ }^{82}$, казалось бы, самой благотворной темы для такого чувственного ракурса рассмотрения, он почти совсем уходит, поскольку среди собеседников не оказывается женщин. Командор, озвучивающий авторскую позицию, хотя и испытывает порой досаду и сожаление и приводит всяческие чувственные аналогии, все время аргументирует свою позицию с точки зрения логики и прагматизма. Аргументы женщин всегда ограничены чувственным восприятием - «я

80 Callières. 1695: 54.

81 Callières. 1695: 55.

82 Callières. 1971. 


\section{Стогова А.В. Запах слов}

также терпеть не могу...»,83 «...это не единственное слово, которое пришлось мне не по вкусу, - ответила Маркиза, есть и другие, которые мне приходилось выслушивать, с трудом их вынося»,84 «отвращение, которое я питаю к этим словам...».85

Поведение героев беседы также существенно различается, женщины эмоционально реагируют не только на критику, которая вызывает естественное смущение и неловкость или недовольство у всех, но практически на любые слова. В книге о хороших и дурных манерах речи, где манера речи женщин оказывается одним из предметов рассмотрения, на протяжении всего повествования разворачивается интрига, связанная с соперничеством немолодой хозяйки дома и юной и прекрасной Маркизы. Начавшаяся с упоминавшейся выше бестактности господина Тибо, назвавшей хозяйку пожилой дамой, она продолжается в описании отношения обеих дам к Командору. Его правильная и галантная речь оказывается для Дамы источником не меньших страданий, чем грубость господина Тибо, поскольку обращена к сопернице. Раз за разом в репликах Командора и Маркизы Дама слышит не рассуждения о языке, а лишь любезности, обращенные к друг к другу. И столь же последовательно повествователь предоставляет читателю объяснение этого отношения:

Тем самым Аама помешала Командору ответить на мюбезность Маркизы из-за порыва ревности, свойственной большинству женщин, которые не могут спокойно выносить, когАа в их присутствии хва^ят Аругую; ${ }^{86}$ Маркиза посмеялась наА этим примером,

83 Callières. 1693a: 61.

84 Callières. 1693b: 80.

85 Callières. 1693b: 84.

86 Callières. 1693b: 100-101. 
который так поАходил к истории, о которой шла речь. Но Аама не нашла в нем ничего смешного и чуть было не рассердилась на процитировавшего его Командора, а еще больше на Маркизу, за то, что он ее развеселил. Ее мысли были заняты другим. Маркиза была юной и прекрасной, а это - страшное преступление в глазах женщины немолодой, но еще претендующей на то, чтобы слыть красивой. 87

Эти повторяющиеся пассажи, как и другие ремарки, приписывают женщинам чувственное восприятие речи, в ущерб рациональному и, вдобавок меньшую способность контролировать свои страсти. Одна из немногих историй о женской речи, включенная в повествование, посвящена тому, как две знатные дамы рассорились из-за подписи в письме, поскольку одна «не могла простить» другой неверно употребленного в нем слова. 88

Такое описание определяет в качестве идеала человека здравомыслящего и контролирующего свои страсти и в этом отношении все критикуемые мужчины также в той или иной мере от него отклоняются; в то же время именно мужчина выступает в качестве воплощения этого идеала. Это подчеркивают и разнообразные сравнения, которые появляются в тексте:

Но что изряано их [приАворных, занятых мишь пустословием и собственной персоной - А.С.] балует и подАерживает их высокое мнение о собственной персоне, так это множество дураков и женщин в столице и провинции, которые восхищаются ими, как говорится, с головы Ао ног, и беспрестанно копируют их манеру говорить вплоть до акцента, их жесты, позы и гримасы, даже самые смешные. ${ }^{89}$

87 Callières. 1693b: 112-113.

88 Callières. 1693b: 225-226.

89 Callières. 1693a: 194-195. 


\section{Стогова А.В. Запах слов}

Командор, подводя итоги размышлений, отмечает, что «для того, чтобы хорошо говорить и писать, следует начать с размышлений; а для того, чтобы ясно мыслить, необходимо приучить себя размышлять обо всем в свободное время. Следует также научиться противиться силе живого воображения, которое заставляет тех, кто отдается на его волю, среди приятностей говорить вещи несправедливые и неуместные». 90

Однако при этом, несложно заметить, что женщины, как и мужчины-придворные, представлены в обеих книгах в совершенно ином качестве, нежели герои-буржуа. Даже говоря неправильно сами, они способны выступать в качестве арбитра чужой речи, что резко отличает их от участвующих в беседе горожан. И Дама, и Маркиза на протяжении обоих текстов принимают самое активное участие в беседе, предлагая новые выражения для обсуждения и критики, и чувствуя себя вполне компетентными для этого занятия, декларируя свое невежество, ${ }^{91}$ лишь когда речь заходит о том, что есть слова, «которые сами по себе хороши, но складываются в дурную речь, если они ставятся не на свое место, плохо составлены и не сочетаются с другими словами».92 Более того, после того как примеры и объяснения ошибок были даны, Маркиза замечает, что это помогло ей прояснить «идеи, которые я представляла себе, но очень смутно» (qui n'étoient que confusément dans mon esprit). ${ }^{93}$ Таким образом, рассужде-

90 Callières. 1693b: 133-134.

91 «Я бы очень хотела, сказала Маркиза, чтобы вы привели нам несколько примеров этих неАостатков, чтобы дать о них точное преАставление и помочь невежественным особам вроде меня совершать их чуточку реже". Callières. 1693b: 123.

92 Callières. 1693b: 123.

93 Callières. 1693b: 142. 
ния о женской манере речи помогают подчеркнуть значимость знаний и рационалистического подхода к языку и постулировать, что необходимые знания включают значения слов, правила речи и всевозможные исключения, определяемые той ситуацией, в которой ведется беседа. ${ }^{94}$ Но вместе с тем невежественность женщин-аристократок подчеркивает важность и другого качества - вкуса, позволяющего оценивать чужую речь на уровне чувств, на основе «смутных представлений». Это то, чего лишены буржуа (за некоторым оговариваемым исключением) из-за своей привычки к дурному образу жизни, и в силу чего из них получаются лишь «дурные копиисты» правильной манеры речи (женщин это касается в той же мере, как и мужчин: горожанки, подражающие знатным дамам, выставляют себя на посмешище ${ }^{95}$ ). После всех рассуждений об отличии речи придворных от речи буржуа, Аббат (который, напомним, описан как представитель почтенного парижского семейства, любящий общение с дамами) замечает, что во всех эти «тонкостях, которые нужны лишь для того, чтобы определить, какое из двух слов, обозначающих одно и то же, следует выбрать», нет ничего разумного, это - лишь прихоть фантазии, а значит, вполне можно было бы «с легкостью обойтись без знания всех этих различий и умения пользоваться этим знанием на деле».96 На эту буржуазную прагматичность немедленно следует комментарий Командора, что обойтись можно вообще без всего, кроме еды и питья, а предложенный им пример того, как выглядело бы письмо, написанное человеком, проигно-

94 Callières. 1693b: 134.

95 Callières. 1693b: 73.

96 Callières. 1693b: 237-238. 
рировавшим все обсуждавшиеся «тонкости», вызвал смех у знатных собеседников и смутил Аббата. ${ }^{97}$

В то же время статус вкуса и разума вовсе не равнозначен. Вкус непременно должен подчиняться контролю со стороны разума, в противном случае он приводит к безудержной и бессмысленной погоне за модой. Это различие и лежит в основе гендерной иерархии и имеет определяющее значение в том, как именно женщины и мужчины представлены в тексте. Статус женщины и мужчины в текстах Кальера коррелируют со значимостью вкуса ${ }^{98}$ и разума в том идеале человека, который стоит за предлагаемой критикой: здравомыслящего, наблюдательного, способного к самоограничению и самосовершенствованию, желающего послужить благу общества и монарха, любезного на словах и в поступках, не претендующего на статус более высокий, чем он имеет, и при этом наделенного вкусом и далекого от прагматичной рациональности буржуа.

Рассуждая впоследствии о знании света, Кальер связывает развитие любезности и вежливости как модели поведения с влиянием женщин, путь к сердцу которых лежит через приятные слова, но и это влияние подчеркивает гендерную иерархию:

Также нет ничего, что мучше могло бы отполировать ум мужчины и сделать его приятным в беседе, чем общение с дамами. Именно они вызывают желание понравиться мягкими, вкрадчивыми, Аеликатными манерами, и именно в общении с ними мужчины знакомятся с большинство норм приличия, которые приняты среди светских ^юАей и которые составляют значительную часть знания света. ${ }^{99}$

97 Callières. 1693b: 238-239.

98 Тезис также вполне традиционный Аля того времени. См. об этом: Chantalat. 1992; Timmermans. 1993.

99 Callières. 1717: 23. 
В качестве вдохновляющей помощницы и благодарной ученицы в обоих текстах представлена Маркиза - главный положительный женский персонаж полилогов.

В целом можно сказать, что подчеркивание чувственной составляющей речи и светской беседы оказывается одним из ключевых аргументов Кальера. Речь в его изображении оказывается очень тесно связанной как с тем, что чувственное и эмоциональное восприятие первично по отношению к разуму, так и с влиятельностью страстей. Именно это и становится основой для классицистической концепции языка и рационалистической идеи человека, а также критики как феномена моды, так и невежества, маркирующих разные оппозиции по отношению к этому идеалу. В основе этой идеи лежит специфический образ человека, для которого беседа важна не сама по себе, как способ приятного времяпрепровождения, но который видит в ней инструмент влияния и желает преуспеть. Он не может себе позволить говорить то, что ему вздумается и как ему вздумается, поскольку хочет получить точно рассчитанный результат. Эта позиция человека, нацеленного на то, чтобы добиться успеха, превращает язык и «знание света» в науку, которая требует изучения, и делает знания и способность разумно мыслить важнейшей характеристикой человека. Кальер уподобляет речь человека архитектурному строению, как из камней составленному из отдельных слов. Нельзя полагаться лишь на прихоть и вкус, строя такое здание, невозможно просто следовать моде и копировать то, что построено другими. Все отдельные его элементы «вплоть до ниш и рокайлей» и прочих украшений должны быть тщательно отобраны и со знанием дела помещены на нужное место. 100

100 Callières. 1693b: 139. 
Кальер гораздо более эксплицитно, нежели его предшественники, рассуждавшие о «человеке достойном» и хороших манерах ${ }^{101}$, связывает этот идеал с человеком, находящимся на королевской службе и стремящимся на этой службе составить себе положение, вопреки сословной иерархии. Прозрачность рассуждений Кальера говорит о том, что подобные люди уже имели достаточно прочное положение в обществе.

101 Среди которых был и отец Кальера. 


\section{Список источников и китературы}

\section{Источники}

Арно, Лансло. 1990 - Арно А., Лансло К. Грамматика общая и рациональная. М.: Прогресс, 1990.

Каллиер. 1772 - Каллиер Ф. Каким образом договариваться с государями или о пользе договоров, о избрании послов и посланников, и о качествах нужных для получения успеха в сих званиях. Сочинение г. Каллиера, обыкновеннаго королевскаго советника в его советах, кабинетнаго секретаря Его величества, прежде бывшаго чрезвычайным и полномочным послом покойнаго короля при мирных договорах заключенных в Ризвике, и одного из сорока членов Академии француской со многими прибавлениями $\mathrm{M}^{* * *}$. Часть перьвая. Переведена с францускаго ризвикскаго издания 1757 году. СПб., 1772.

Кальер. 2000 - Кальер Ф. де. 0 способах ведения переговоров с государями / Пер. и коммент. Л. А. Сифуровой. М.: Гендальф, 2000.

Callières. 1693a - Callières F. Des mots à la mode et des nouvelles façons de parler : avec des observations sur diverses manières d'agir ... P.: Chez Claude Barbin, 1693.

Callières. 1693b - Callières F. Du bon et du mauvais usage dans les manières de s'exprimer. Des façons de parler bourgeoises. Et en quoy elles sont différentes de celles de la cour. Suitte des mots à la mode. P.: Chez Claude Barbin, 1693.

Callières. 1695 - Callières F. Du bel esprit. Où sont examinez les sentimens qu'on en a d'ordinaire dans le monde. P.: Chez Jean Anisson, 1695.

Callières. 1717 - Callières F. De la science du monde, et des connoissances utiles à la conduite de la vie. P.: Chez Etienne Ganeau, 1717.

Callières. 1971 - Callières F. Des bons mots et des bons contes (1692). Genève : Slankine reprints, 1971.

Collection de documents. 1885 - Collection de documents pour servir à l'histoire des hôpitaux de Paris commencée sous les auspices de M. Michel Möring ; continuée par M. Charles Quentin,... ; publiée par M. Brièle,.. P.: Imp. nat., 1881-1887. Vol. IV. 1885. 
D'Alembert. 1967 - D'Alembert. Oeuvres d'Alembert. Génève: Slatkine, 1967.

Goujet. 1756 - Goujet C.P. Bibliothèque françoise, ou Histoire de la littérature françoise. P. : P.-J. Mariette, H.-L. Guerin, 1756.

Moreri. 1759 - Moreri L. Le grand dictionnaire historique du Moreri. P. : Chez libraries associés, 1759.

Piganiol de La Force. 1742 - Piganiol de La Force J.-A. Description de Paris, de Versailles, de S. Cloud, de Fontainebleau et de toutes les autres belles maisons et châteaux des environs de Paris. P.: Au Palais chez Theodore Legras, 1742.

\section{\ИТЕРАТУРА}

Стогова. 2017 - Стогова А.В. Портрет женского голоса во французской салонной культуре XVII века // Адам \& Ева. Альманах гендерной истории. Вып. 25. М.: ИВИ РАН, 2017. С. 189-239.

Фуко. 1994 - Фуко М. Слова и вещи. Археология гуманитарных наук. СПб.: A-cad, 1994.

Хомский. 2005 - Хомский Н. Картезианская лингвистика. Главы из истории рационалистической мысли. М.: УРСС, 2005.

Элиас. 2001 - Элиас Н. О процессе цивилизации. М.-СПб.: Университетская книга, 2001. T. I-II.

A Cultural History of the Senses. 2014 - A Cultural History of the Senses. Vol. 4. In the Age of Enlightenment / ed. by A.C. Vila. L., New Delhi, N.Y., Sydney: Bloomsbury, 2014.

Chantalat. 1992 - Chantalat C. À la recherche du goût classique. P. : Klincksieck, 1992.

Chométy. 2006 - Chométy Ph. Philosopher en langage des dieux: La poésie d'idées en France au siècle de Louis XIV. P.: Honoré Champion, 2006.

Dens. 1981 - Dens J.-P. L'honnête homme et la critique du goût : esthétique et société au XVIIe sièle. Lexing-ton: French Forum, 1981.

James. 2003 - James S. Passion and Action. The Emotions in Seventeenth-Century Philosophy. Oxford: Clarendon press, 2003.

Lempereur. 2002 - Lempereur A.P. Aux sources des théories de la négotiation : l'oeuvre fondatrice de François de Callières // Callières F. De la manière de négocier avec les souverains / Ed. Critique par A.P. Lempereur. Genève : Librarie Droz, 2002. P. 7-50. 
Maitre. 1999 - Maitre M. Les précieuses. Naissance des femmes de lettres en France au XVIIe siècle. P. : Honoré Champion, 1999.

Nancy. 2012 - Nancy S. La voix féminine et le plaisir de l'écoute en France aux XVIIe et XVIIIe siècles. P. : Garnier, 2012.

Pizzorusso. 1968 - Pizzorusso A. Teorie letterarie in Francia. Pisa: Nistri-Lischi, 1968.

Pope. 2010 - Pope L. François de Callières: a Political Life. Dordrecht : Republic of Letters Publishing, 2010.

Reading Early Modern Passions. 2004 - Reading Early Modern Passions / ed. by G.K. Paster, K. Rowe and M. Floyd-Wilson. Philadelphia: University of Pennsylvania Press, 2004.

Timmermans. 1993 - Timmermans L. L'accès des femmes à la culture (1598-1715): un débat d'idées de Saint François de Sales à la Marquise de Lambert. P.: Honoré Champion, 1993

Schweizer. 1995 - Schweizer K.W. François de Callières: diplomat and men of letters, 1645-1717. Lewiston: The Edwin Mellen Press, 1995.

Waquet. 2005 - Waquet J.-C. François de Callières. L'art de dégocier en France sous Louis XIV. P. : Editions rue d'Ulm, 2005. 